\title{
A REVIEW OF THE ETHNOMEDICINAL USES, PHYTOCHEMISTRY AND PHARMACOLOGICAL PROPERTIES OF EKEBERGIA CAPENSIS SPARRM
}

\author{
ALFRED MAROYI* \\ Department of Botany, Medicinal Plants and Economic Development Research Centre, University of Fort Hare, Private Bag X1314, \\ Alice 5700, South Africa. Email: amaroyi@ufh.ac.za
}

Received: 07 August 2018, Revised and Accepted: 29 August 2018

\begin{abstract}
Ekebergia capensis is an integral part of indigenous pharmacopeia in tropical Africa. The present study critically reviewed the ethnomedicinal uses, phytochemistry, and pharmacological properties of E. capensis. The keywords including E. capensis, its synonyms, English common names, ethnomedicinal uses, and phytochemistry and pharmacological properties of the species were searched using electronic databases such as ISI web of knowledge, ProQuest, science direct, OATD, Scopus, Open-thesis, PubMed, and Google Scholar. Pre-electronic literature search of conference papers, scientific articles, books, book chapters, dissertations, and theses was carried out at the University Library. Literature studies revealed that E. capensis is mainly used as herbal medicine against fever and malaria, gastrointestinal problems, pain, parasitic worms, reproductive problems in women, respiratory problems, and skin diseases. Phytochemical compounds identified from the species include alkaloids, anthraquinones, coumarins, flavonoids, glycoflavonoids, glycosides, iridoids, limonoids, polyphenols, phytosteroids, pregnane, saponins, tannins, and withanolides. Pharmacological studies revealed that E. capensis extracts and compounds have acetylcholinesterase-inhibitory, analgesic and anti-inflammatory, anthelmintic, antibacterial, antifungal, antigonococcal, antimycobacterial, antimycoplasmal, antihypertensive, antioxidant, antimalarial and antiplasmodial, antischistosomal, antitrypanosomal, and antiviral and cytotoxicity activities. Although pharmacological evaluations carried out so far have confirmed the potency of E. capensis crude extracts and compounds, detailed studies are required aimed at establishing the efficacy, clinical relevance, safety, and mechanisms of action of the plant extracts and compounds.
\end{abstract}

Keywords: Ekebergia capensis, Meliaceae, Traditional medicine, Tropical Africa.

(C) 2018 The Authors. Published by Innovare Academic Sciences Pvt Ltd. This is an open access article under the CC BY license (http://creativecommons. org/licenses/by/4. 0/) DOI: http://dx.doi.org/10.22159/ajpcr.2018.v11i10.28816

\section{INTRODUCTION}

Ekebergia capensis Sparrm. (Family Meliaceae) is an important component of the indigenous pharmacopeia in South Africa where the bark, sometimes the leaves or roots are used as an emetic, vermifuge, abscesses, acne, acute gastritis, boils, chronic cough, dysentery, headache, heartburn, and scabies [1]. According to George et al. [2], E. capensis has potential as a commercial source of the compound limonoid ekebergin for vermifuge and emetic drugs. E. capensis is an integral part of the Materia Medica in South Africa, used regularly and included in the book "medicinal plants of South Africa" written by Van Wyk et al. [1]. Based on its wide application as herbal medicine, the bark of E. capensis is marketed as traditional medicine in informal herbal medicine markets and other informal markets in Gauteng and KwaZulu Natal provinces in South Africa [3,4]. According to Neuwinger [5], the leaves, roots, and stem bark of E. capensis are used as fish poison in the Democratic Republic of Congo (DRC) and Nigeria. The family Meliaceae is pantropical in distribution, consisting of trees and shrubs recorded in rainforests, with some taxa confined to seasonally dry forests, mangroves, and tropical woodlands [6]. At the present moment, about 50 genera and 700 species are recognized in the family worldwide $[6,7]$. Close to a third of these species (223 species) are threatened with extinction, listed in the 2018 IUCN Red List of Threatened Species as critically endangered, vulnerable, or endangered [8]. Among these are Entandrophragma candollei Harms, Entandrophragma angolense (Welw.) C. DC., Entandrophragma utile (Dawe and Sprague) Sprague, Entandrophragma cylindricum (Sprague) Sprague, Khaya grandifoliola C. DC., Khaya anthotheca (Welw.) C. DC., K. madagascariensis Jum. and Perr., K. ivorensis A. Chev., and Khaya senegalensis (Descr.) A. Juss. which are listed as vulnerable or endangered [8] and used as timber and traditional medicines in tropical Africa [9]. In recent years, members of the Meliaceae family have attracted considerable attention as an important source of limonoids and tetranortriterpenoids with insecticidal, antifeedant, and other pharmacological properties [10]. It is within this context that the chemical composition, pharmacological properties, and medicinal uses of E. capensis were reviewed aimed at evaluating the therapeutic potential of the species.

\section{BOTANICAL PROFILE OF E. CAPENSIS}

The genus Ekebergia sparrm. is in honor of a Swedish physician and chemist, Captain Carl Gustaf Ekeberg (1716-1784), whose sponsorship in the $18^{\text {th }}$ century made it possible for Anders Sparrman, the author of the genus and the species E. capensis to visit Africa [11,12]. The specific name "capensis" means "from the Cape" in reference to the Cape province in South Africa where the type specimen was collected from. The genus Ekebergia consists of four species globally, E. capensis, Ekebergia benguelensis Welw. ex C. DC., Ekebergia pterophylla (C. DC.) Hofmeyr, and Ekebergia pumila I. M. Johnst $[11,13,14]$. E. capensis is a semi-deciduous or evergreen, large to medium-sized tree growing up to $100 \mathrm{~cm}$ in diameter and $35 \mathrm{~m}$ in height $[11,12,15]$. The bole is usually straight or sometimes crooked, branchless for up to $12 \mathrm{~cm}$; stem may be swollen, buttressed and fluted in forests or short, and unfluted in open woodland [11]. The young stems are dotted circular leaf scars and whitish lenticels. Leaves are compound, alternate or crowded at the ends of branchlets. The leaflets are 3-7 pairs per leaf, glossy green in color, margin entire and may be waxy, with an asymmetric base, sessile, opposite, with a terminal leaflet and sometimes with a drip-tip [15]. Flowers are small, greenish-yellow, or white in color, sweetly scented, with male and female flowers on different trees. Fruits are fleshy and succulent, subglobose, pink to bright red in color when ripe [11]. The seeds are white in color and oval in shape; a fruit usually produces $2-4$ seeds $[11,15]$

E. capensis is widespread in tropical and subtropical Africa, from Senegal east to Eritrea and Ethiopia and south to Botswana, eastern South Africa and Swaziland (Fig. 1). E. capensis has been recorded in dry, Afromontane and riverine forests on well drained and deep 


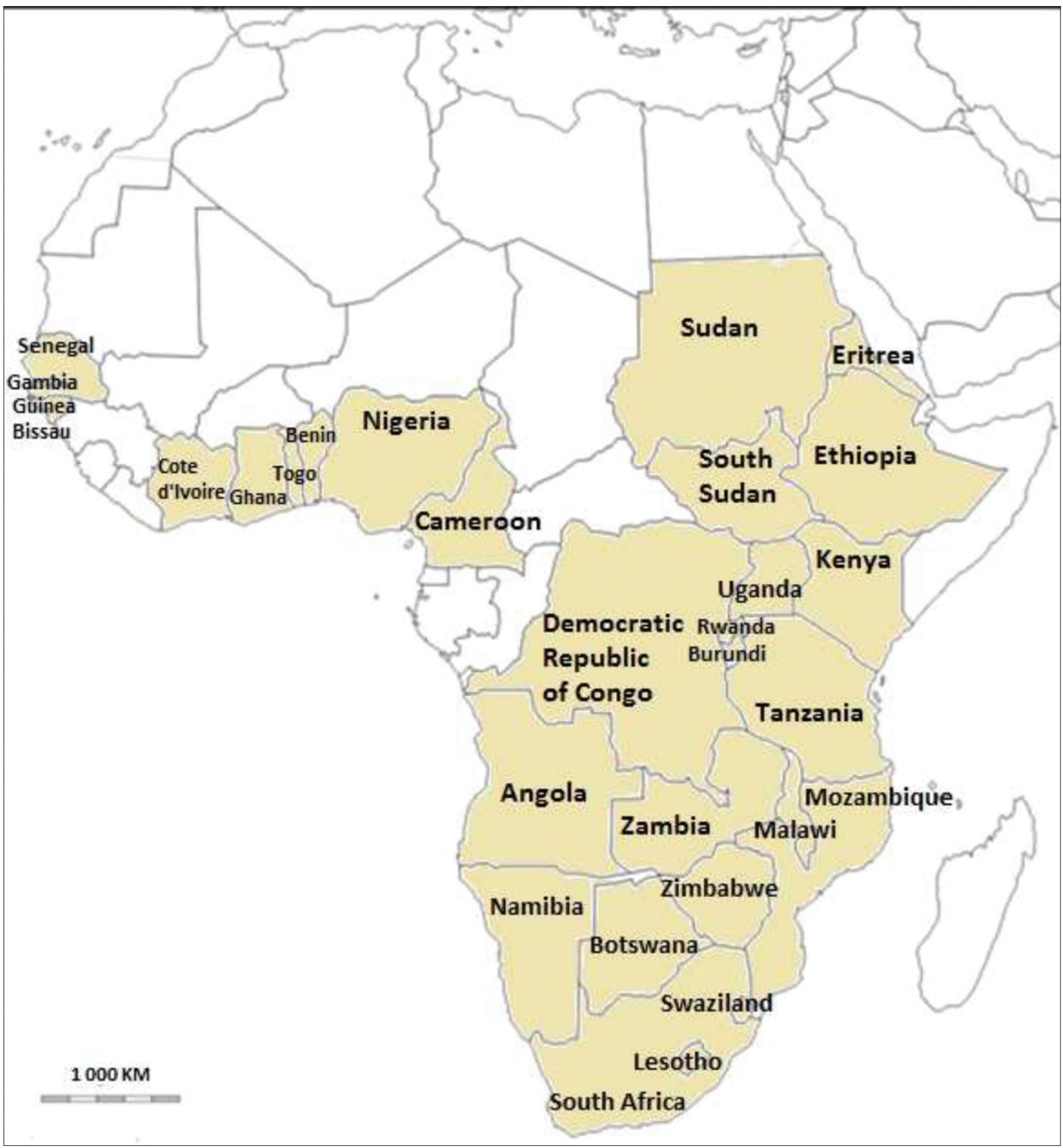

Fig. 1: Distribution of Ekebergia capensis in tropical Africa

sandy soils at an altitude ranging from $600 \mathrm{~m}$ to $3000 \mathrm{~m}$ above sea level and different rainfall regimes ranging from $750 \mathrm{~mm}$ to $2000 \mathrm{~mm}$ per annum [16]. In the savanna woodland and wooded grassland, E. capensis has been recorded on termite mounds [15].

\section{MEDICINAL USES OF E. CAPENSIS}

The bark, fruits, leaves, roots, stem bark, and wood of E. capensis are used as remedies for human and animal diseases (Table 1). Information on medicinal uses of the species has been found in Cameroon, Ethiopia, South Africa, Kenya, Uganda, Nigeria, and Swaziland. Major diseases recorded in at least three countries include fever and malaria, gastrointestinal problems, pain, parasitic worms, reproductive problems in women, respiratory problems, and skin diseases (Fig. 2). In multi-therapeutic applications, the bark maceration of E. capensis is mixed with the bark of Diospyros lycioides Desf. and taken orally as an herbal medicine for blood in feces [17]. The bark decoction of E. capensis is mixed with roots of Euclea natalensis A. DC. and taken orally as an herbal medicine for cough, heartburn, and respiratory complaints [18].

\section{PHYTOCHEMICAL AND NUTRITIONAL COMPOSITION OF E. CAPENSIS}

Several phytochemical compounds and minerals have been identified from leaves, stems, roots, root, and stem bark of E. capensis (Table 2). Other phytochemical compounds identified from the bark, leaves, roots, seeds, stem bark, and twigs of E. capensis include anthraquinones, flavonoids, glycosides, iridoids, polyphenols, phytosteroids, saponins, tannins, and withanolides [48,55-57]. Total flavonoids, gallotannins, iridoids, phenolics, and condensed tannins content of various parts of E. capensis are shown in Table 3. Some of the phytochemical compounds isolated from E. capensis demonstrated various biological activities and these include antiplasmodial activities exhibited by compounds 8,24 [58], 23, 41, and 42 [59], in vivo antimalarial activities exhibited by compound 24 [58], cytotoxic activities 
Table 1: Medicinal uses of Ekebergia capensis

\begin{tabular}{|c|c|c|c|}
\hline Medicinal use & Parts of the plant used & Country & References \\
\hline \multicolumn{4}{|l|}{ Monotherapeutic applications } \\
\hline Anthrax infection & Leaves & South Africa & [19] \\
\hline Blood purifier & Leaves & South Africa & [19] \\
\hline Blood pressure & Leaves & South Africa & [19] \\
\hline Cancer (breast, skin, and throat) & Bark, fruits, and leaves & Ethiopia and Kenya & {$[20,21]$} \\
\hline $\begin{array}{l}\text { Charms and casting of spells (love charm, } \\
\text { protection of homestead and ward off evil } \\
\text { spirits) }\end{array}$ & Bark and stem & South Africa and Swaziland & {$[22-24]$} \\
\hline Disinfectant & Bark & South Africa & {$[23]$} \\
\hline Emetic & Bark and leaves & South Africa and Swaziland & {$[1,18,23-26]$} \\
\hline Epilepsy & Leaves & Nigeria & [27] \\
\hline Ethnoveterinary medicine & $\begin{array}{l}\text { Bark, flowers, fruits, leaves, } \\
\text { roots, and stems }\end{array}$ & Ethiopia and Kenya & [28-32] \\
\hline Exhaustion & Bark & South Africa & {$[23]$} \\
\hline Fever and malaria & $\begin{array}{l}\text { Bark, leaves, roots, and stem } \\
\text { bark }\end{array}$ & $\begin{array}{l}\text { Ethiopia, Kenya, Nigeria, } \\
\text { and Uganda }\end{array}$ & {$[27,33-38]$} \\
\hline Health tonic & Bark & Kenya & {$[34]$} \\
\hline $\begin{array}{l}\text { Heart problems (heartburn and heart } \\
\text { problems) }\end{array}$ & Bark, leaves, and roots & South Africa & {$[1,12,18,19,23]$} \\
\hline Liver complaints & Leaves & South Africa & [19] \\
\hline Mental problem & Leaves & South Africa & {$[41]$} \\
\hline $\begin{array}{l}\text { Reproductive problems (induce labor, } \\
\text { infertility, menstrual problems, and } \\
\text { ovarian cyst) }\end{array}$ & Bark, stem bark, and wood & $\begin{array}{l}\text { Cameroon, Ethiopia, and } \\
\text { South Africa }\end{array}$ & {$[23,42-44]$} \\
\hline $\begin{array}{l}\text { Pain (backache and headache, jaw } \\
\text { swelling, and pain) }\end{array}$ & Bark, leaves, and stems & $\begin{array}{l}\text { Ethiopia, Kenya, and South } \\
\text { Africa }\end{array}$ & {$[1,12,17,24-26,29,32,36,45,46]$} \\
\hline Parasitic worms (intestinal worms) & Bark, leaves, and stem bark & $\begin{array}{l}\text { Kenya, South Africa, and } \\
\text { Swaziland }\end{array}$ & {$[1,12,23,24,47]$} \\
\hline $\begin{array}{l}\text { Respiratory problems (chest pains, cold, } \\
\text { cough, respiratory complaints, and runny } \\
\text { nose) }\end{array}$ & $\begin{array}{l}\text { Bark, leaves, roots, and stem } \\
\text { bark }\end{array}$ & $\begin{array}{l}\text { Ethiopia, Kenya, South } \\
\text { Africa, and Swaziland }\end{array}$ & {$[1,12,18,23,25,26,29,36,40,47-50]$} \\
\hline Snakebite & Leaves and roots & Uganda & [37] \\
\hline Sores & Bark & South Africa & {$[41]$} \\
\hline Venereal diseases & Bark, leaves, and roots & Kenya and South Africa & {$[25,26,54]$} \\
\hline Vermifuge & Leaves & South Africa & [1] \\
\hline Weight loss & Bark & Ethiopia & [32] \\
\hline \multicolumn{4}{|l|}{ Multi-therapeutic applications } \\
\hline Blood in feces & $\begin{array}{l}\text { Bark maceration taken orally } \\
\text { mixed with those of Diospyros } \\
\text { lycioides Desf. }\end{array}$ & South Africa & [17] \\
\hline $\begin{array}{l}\text { Cough, heartburn, and respiratory } \\
\text { complaints }\end{array}$ & $\begin{array}{l}\text { Bark mixed with roots of Euclea } \\
\text { natalensis A. DC. }\end{array}$ & South Africa & [18] \\
\hline
\end{tabular}

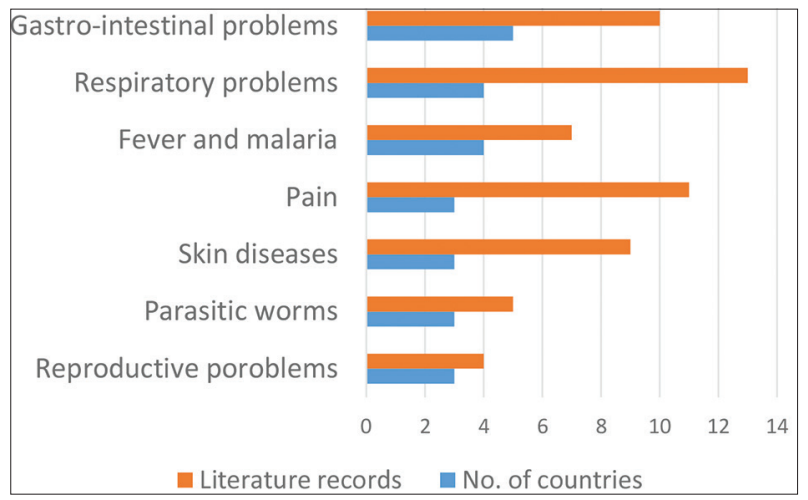

Fig. 2: Diseases treated by Ekebergia capensis in tropical Africa

exhibited by compounds $23,24,26$, and 43 [60], and toxicity activities demonstrated by compounds 9 and 10 [61].

\section{PHARMACOLOGICAL ACTIVITIES OF E. CAPENSIS}

Some of the pharmacological activities of E. capensis listed in literature include acetylcholinesterase-inhibitory [57], analgesic and anti-inflammatory $[26,69,70]$, anthelmintic $[55,71]$, antibacterial $\quad[25,51,56,72,73], \quad$ antigonococcal $\quad[25,67]$, antimycobacterial 74], antimycoplasmal [47], antifungal [25,56,72,73], antihypertensive $[19,75]$, antioxidant $[27,57,68,76]$, antimalarial and antiplasmodial [33,34,58,59,77-79], antischistosomal [80], antitrypanosomal [81], and antiviral [25,60] and cytotoxicity $[26,34,59,60,76,82-84]$ activities. These pharmacological activities of various parts of the species are summarized below.

\section{Acetylcholinesterase inhibitory}

Amoo et al. [57] evaluated acetylcholinesterase inhibitory properties of E. capensis using colorimetric assay with galanthamine at $20 \mu \mathrm{M}$ as a positive control. Acetylcholinesterase inhibition (\%) at $1.0 \mathrm{mg} / \mathrm{ml}$ was 73.8\%-89.7\%.These results suggest that E. capensis extracts deserve further investigation as they may provide secondary metabolites which 
Table 2: Phytochemical compounds identified from Ekebergia capensis

\begin{tabular}{|c|c|c|c|c|}
\hline No. & Compound & $\begin{array}{l}\text { Method of } \\
\text { compound } \\
\text { analyzes }\end{array}$ & Plant part & References \\
\hline & Alkaloid & & & \\
\hline \multirow[t]{2}{*}{1} & Ekeberginine & NMR & Stem bark & {$[62]$} \\
\hline & Coumarins & & & \\
\hline 2 & Ekersenin & NMR & Stem bark & {$[58,63]$} \\
\hline 3 & 4,6-dimethoxy-5-methylcoumarin & NMR & Stem bark & [58] \\
\hline 4 & 7-hydroxy-6-methoxycoumarin & NMR & Wood & {$[42]$} \\
\hline \multirow[t]{2}{*}{5} & Xanthoxyletin & NMR & Stem bark & {$[62]$} \\
\hline & Glycoflavonoids & & & \\
\hline 6 & Kaempferol-3-0- $\beta$-D-glucopyranoside & MS and NMR & Leaves & {$[59]$} \\
\hline \multirow[t]{2}{*}{7} & Quercetin-3-0- $\beta$-D-glucopyranoside & MS and NMR & Leaves & [59] \\
\hline & Limonoids & & & \\
\hline 8 & 7-deacetoxy-7-oxogedunin & NMR & Stem bark & {$[58]$} \\
\hline 9 & Capensolactones l & MS and NMR & Seeds & [61] \\
\hline 10 & Capensolactones 2 & MS and NMR & Seeds & {$[61]$} \\
\hline 11 & Capensolactones 3 & MS and NMR & Seeds & {$[61]$} \\
\hline 12 & Ekebergin & NMR & Seeds & {$[64]$} \\
\hline 13 & Methyl 3x-hydroxy-3-deoxyangolensate & MS and NMR & Seeds & {$[61]$} \\
\hline 14 & Methylangolensate & NMR & Stem bark & {$[58]$} \\
\hline 15 & Mexicanolide & NMR & Stem bark & {$[58]$} \\
\hline \multirow[t]{2}{*}{16} & Proceranolide & MS and NMR & Leaves and stem bark & {$[58,59]$} \\
\hline & Phenolic & & & \\
\hline \multirow[t]{2}{*}{17} & Atraric acid & NMR & Bark & {$[65]$} \\
\hline & Phytosterol & & & \\
\hline 18 & $\beta$-sitosterol & NMR & Bark and wood & {$[42,65]$} \\
\hline 19 & $\beta$-sitosterol oleate & NMR & Bark & {$[65]$} \\
\hline \multirow[t]{2}{*}{20} & $\beta$-sitosterol palmitate & NMR & Bark & {$[65]$} \\
\hline & Pregnane & & & \\
\hline \multirow[t]{2}{*}{21} & (Z)-volkendousin & NMR & Stem bark & {$[58]$} \\
\hline & Triterpenoids & & & \\
\hline 22 & $\begin{array}{l}\text { 2,3,22,23-tetrahydroxy-2,6,10,15,19,23- } \\
\text { hexamethyl-6,10,14,18-tetracosatetraene }\end{array}$ & NMR & Bark, stem bark and wood & {$[42,58,59,66]$} \\
\hline \multirow[t]{2}{*}{23} & 2-hydroxymethyl-2,3,22,23-tetrahydroxy & NMR & Bark and stem bark & {$[58,59,66]$} \\
\hline & $-6,10,15,19,23$-pentamethyl-6,10,14,18-tetracosatetraene & & & \\
\hline 24 & 3,11-dioxoolean-12-en-28-oic acid & NMR & Stem bark & {$[58]$} \\
\hline 25 & 3-epi-oleanolic acid & MS and NMR & Bark, root bark, stem bark, and wood & {$[42,58,59,65,66]$} \\
\hline 26 & 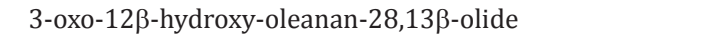 & MS and NMR & Root bark and stem bark & {$[58,59]$} \\
\hline 27 & 7-acetylneotrichilenone & NMR & Stem bark & {$[58]$} \\
\hline 28 & Ekeberins A & MS and NMR & Root bark and stem bark & {$[58,59]$} \\
\hline 29 & Ekeberins B & NMR & Stem bark & [58] \\
\hline 30 & Ekeberins C1 & NMR & Stem bark & [58] \\
\hline 31 & Ekeberins C2 & NMR & Stem bark & [58] \\
\hline 32 & Ekeberins C3 & NMR & Stem bark & {$[58]$} \\
\hline 33 & Ekeberins D1 & NMR & Stem bark & [58] \\
\hline 34 & Ekeberins D2 & NMR & Stem bark & {$[58]$} \\
\hline 35 & Ekeberins D3 & NMR & Stem bark & {$[58]$} \\
\hline 36 & Ekeberins D4 & NMR & Stem bark & {$[58]$} \\
\hline 37 & Ekeberins D5 & NMR & Stem bark & {$[58]$} \\
\hline 38 & Lupeol & NMR & Bark & [65] \\
\hline 39 & Melliferone & NMR & Stem bark & [58] \\
\hline 40 & Oleanolic acid & NMR & Bark and stem bark & {$[58,66]$} \\
\hline 41 & Oleanolic acid & MS and NMR & Bark, root bark, and stem bark & {$[58,59,66]$} \\
\hline 42 & Oleanolic acid & MS and NMR & Bark, root bark, stem bark, and wood & {$[42,58,59,65,66]$} \\
\hline 43 & Swietenolide & NMR & Stem bark & {$[58]$} \\
\hline
\end{tabular}

Table 3: Total flavonoids, gallotannins, iridoids, phenolics, and condensed tannins content of Ekebergia capensis

\begin{tabular}{|c|c|c|c|}
\hline Phytochemical composition & Values & Plant parts & References \\
\hline Condensed tannins (\% leukocyanidin equivalents) & $0.32-0.47$ & Bark and leaves & [25] \\
\hline Flavonoids ( $\mu$ g catechin equivalents/g dry weight) & $1.48-4.84$ & Bark and leaves & [25] \\
\hline Gallotannin ( $\mu$ g gallic acid equivalents/g dry weight) & $35.37-70.00$ & Bark and leaves & [25] \\
\hline Total condensed tannins (mg cyanidin chloride equivalents/g dry weight) & 12.5 & Leaf & [67] \\
\hline Total flavonoids (mg catechin equivalent/g dry weight) & $22.8--26.8$ & Leaf & {$[57,67]$} \\
\hline Total iridoids ( $\mu$ g harpagoside equivalents/g dry weight) & $547.6-2221.5$ & Leaves and twigs & [57] \\
\hline Total phenolics (mg gallic acid equivalents/g dry weight) & $9.63-45.0$ & Brak, leaves and twigs & {$[25,57,67,68]$} \\
\hline
\end{tabular}


can act as natural acetylcholinesterase inhibitors required for the treatment of neurodegenerative disorders.

\section{Analgesic and anti-inflammatory}

William et al. [70] evaluated the analgesic activities of aqueous stem bark extracts of E. capensis in albino rats using a hot plate and tail immersion tests. Rats were administered with doses of $100 \mathrm{mg} / \mathrm{kg}$ and $200 \mathrm{mg} / \mathrm{kg}$ intraperitoneally, and a standard drug pentazocine $10 \mathrm{mg} / \mathrm{kg}$ was used. The extract showed activities which were dosedependent, and the activities were comparable to that of pentazocine in the hot plate method but higher than pentazocine in the tail immersion method. At the dosage of $200 \mathrm{mg} / \mathrm{kg}$ body weight, the latency period increased from $21.4 \mathrm{~min}$ at pre-treatment to $48.2 \mathrm{~min}$ and $59.4 \mathrm{~min}$ and $15 \mathrm{~min}$ and $30 \mathrm{~min}$ post-treatment, respectively. The result of extract on tail immersion test response showed that there were no significant changes in the time for tail withdrawal at all dosages of extract administered except at $100 \mathrm{mg} / \mathrm{kg}$ body weight and $200 \mathrm{mg} / \mathrm{kg}$ body weight where the time for tail withdrawal was significantly shorter than that of the pre-treatment [70]. Comparing reaction times obtained for animals treated with the extracts and the control values, it was apparent that the extracts caused prolongation of latency times, which is indicative of centrally mediated activity.

Jäger et al. [69] evaluated aqueous and ethanolic root extracts of E. capensis in an in vitro assay for cyclooxygenase (COX) inhibitors with indomethacin $(0.5 \mu \mathrm{g})$ as the control. The ethanolic extract of E. capensisshowedinhibition of $82 \%$ which was $>66.5 \%$ inhibition exhibited by the indomethacin control. Based on these results, the RE might be a rationale for the ethnopharmacological claim that E. capensis possess anti-inflammatory properties. Mulaudzi et al. [26] evaluated the anti-inflammatory activities of dichloromethane, ethanol, petroleum ether, and water bark, and leaf extracts of E. capensis against the COX (COX-1 and COX-2) enzymes. All the solvent extracts showed moderate to high (40-90\%) inhibition activity toward COX-1, and insignificant to high $(<20-85 \%)$ inhibition activity toward COX-2 at $250 \mu \mathrm{g} / \mathrm{ml}$ and three further concentrations were evaluated at $31.25 \mu \mathrm{g} / \mathrm{ml}, 62.5 \mu \mathrm{g} / \mathrm{ml}$, and $125 \mu \mathrm{g} / \mathrm{ml}$ to determine inhibitory concentration ( $\mathrm{IC}_{50}$ ) values. Water bark extracts bark showed half maximal $\mathrm{IC}_{50}$ value of $0.01 \mu \mathrm{g} / \mathrm{ml}$ and $0.05 \mu \mathrm{g} / \mathrm{ml}$ toward COX-1 and COX-2, respectively [26]. These results support the traditional use of $E$. capensis in managing inflammatory ailments and diseases such as abscesses and acne in South Africa $[1,41,51,52]$, pain and swelling of jaws in Ethiopia [32,46], and sores in South Africa [41].

\section{Anthelmintic}

McGaw et al. [71] evaluated anthelmintic activities of hexane, ethanol and waterleaf extracts of $E$. capensis on the mortality and reproductive ability of the free-living nematode Caenorhabditis elegans in two different assays. All extracts exhibited activities at a concentration of $2 \mathrm{mg} / \mathrm{ml}$ after the 7 day incubation period, with only water and ethanol extracts showing activities at a concentration of $1 \mathrm{mg} / \mathrm{ml}$ and after $2 \mathrm{~h}$ incubation period, respectively [71]. Eguale et al. [55] evaluated anthelmintic activities of crude aqueous and hydroalcoholic extracts of the seeds of E. capensis on eggs and adult Haemonchus contortus. Both aqueous and hydroalcoholic extracts induced significant egg hatching inhibition with aqueous extract requiring maximum concentration of $0.25 \mathrm{mg} / \mathrm{ml}$ to induce $100 \%$ egg hatch inhibition while the hydroalcoholic extracts did not induce complete inhibition at the highest concentration tested of $2 \mathrm{mg} / \mathrm{ml}$. The aqueous extract induced $50 \%$ inhibition $\left(\mathrm{ED}_{50}\right)$ at $0.06 \mathrm{mg} / \mathrm{ml}$ while the $\mathrm{ED}_{50}$ value of hydroalcoholic extract was $1.03 \mathrm{mg} / \mathrm{ml}$. After $24 \mathrm{~h}$ of exposure of adult $H$. contortus to different concentrations of plant extracts, hydroalcoholic extracts produced motility or mortality of adult $H$. contortus to the level of $60 \%$ at a concentration of $8 \mathrm{mg} / \mathrm{ml}$ while aqueous extract produced only $43.3 \%$ at the same concentration [55]. These findings are comparable to the standard, albendazole which killed the parasites in a dose-dependent manner, and all the worms were dead at a concentration of $0.5 \mathrm{mg} / \mathrm{ml}$ within $24 \mathrm{~h}$ [55]. These biological evaluations are of importance in the traditional use of $E$. capensis as herbal medicine against intestinal worms in Kenya, South Africa, and Swaziland [1,12,23,24,47].

\section{Antibacterial}

Rabe and Van Staden [51] evaluated antibacterial activities of water and methanol bark extracts of E. capensis against Staphylococcus aureus, Staphylococcus epidermis, Bacillus subtilis, Escherichia coli, and Klebsiella pneumoniae using the agar diffusion and dilution methods with neomycin as the positive control. The extracts showed activities against $S$. aureus, $S$. epidermis, and $B$. subtilis with minimum inhibition concentration (MIC) values ranging from $2.0 \mathrm{mg} / \mathrm{ml}$ to $4.0 \mathrm{mg} / \mathrm{ml}$ [51]. Ndukwe et al. [56] evaluated the antibacterial activities of methanol leaf, root, and stem bark extracts of $E$. capensis against B. subtilis, E. coli, Klebsiella, Pseudomonas, Salmonella typhi, and S. aureus using disc diffusion assay. The extracts showed activities with a zone of inhibition ranging from $5 \mathrm{~mm}$ to $23 \mathrm{~mm}$ and MIC value of $6.25 \mu \mathrm{g} / \mathrm{ml}$ [56]. Mulaudzi et al. [25] investigated the antibacterial effects of aqueous, acetone, dichloromethane, ethanol, methanol, and petroleum ether bark and leaf extracts of E. capensis against B. subtilis, E. coli, K. pneumoniae, and S. aureus using microdilution bioassay with neomycin as the positive control. The minimal microbicidal concentration (MMC) of the tested bacteria ranged from $0.39 \mathrm{mg} / \mathrm{mL}$ to $3.13 \mathrm{mg} / \mathrm{mL}$ [25]. Similarly, York et al. [72] assessed the antibacterial properties of aqueous and dichloromethane-methanol (1:1) leaf extracts of E. capensis against K. pneumoniae, Moraxella catarrhalis, Mycobacterium smegmatis, and $S$. aureus using microdilution assay with ciprofloxacin as the positive control. The extract showed activities with MIC values ranging from $1.33 \mathrm{mg} / \mathrm{ml}$ to $16.0 \mathrm{mg} / \mathrm{ml}$ [72]. Mabona et al. [73] evaluated antibacterial activities of aqueous and dichlomethanemethanol (1:1) bark and leaf extracts of E. capensis using the microtiter plate dilution technique against dermatologically relevant pathogens such as Brevibacillus agri, Propionibacterium acnes, Pseudomonas aeruginosa, S. aureus, and S. epidermidis with ciprofloxacin as the positive control and acetone and dimethyl sulfoxide (DMSO) as negative controls. The extracts showed activities with MIC values ranging from $0.38 \mathrm{mg} / \mathrm{mL}$ to $>16.00 \mathrm{mg} / \mathrm{mL}$ [73]. These antibacterial activities displayed by different extracts of $E$. capensis somehow confirm the species' antibacterial potential and its usefulness in the treatment and management of bacterial infections such as boils in South Africa [1,41,51,52], diarrhea in Kenya and Uganda [36,37], dysentery in South Africa [25,26], stomach problems in Ethiopia [21,39], and venereal diseases in Kenya and South Africa $[25,26,54]$.

\section{Antigonococcal}

Mulaudzi et al. [25] evaluated the antigonococcal activities of aqueous, acetone, dichloromethane, ethanol, methanol, and petroleum ether bark and leaf extracts of E. capensis against Neisseria gonorrhoeae through determination of clear zones of inhibition with ciprofloxacin and DMSO as positive and negative controls, respectively. E. capensis showed moderate to high activity with dichloromethane, ethanol, and petroleum ether extracts with percentage inhibition ranging from $45.0 \%$ to $96.0 \%$ [25]. Similarly, Vambe et al. [67] evaluated the antigonococcal activities of dichloromethane, methanol, and petroleum ether and waterleaf extracts of E. capensis against $N$. gonorrhoeae using microdilution and agar disk diffusion techniques with ciprofloxacin as the positive control. All extracts exhibited activities with MIC value of $>2.5 \mathrm{mg} / \mathrm{ml}$. The good antigonococcal activities exhibited by E. capensis extracts tested in this study could lead to the isolation of lead antigonococcal compounds.

\section{Antimycobacterial}

Lall and Meyer [74] evaluated antimycobacterial activities of acetone extract of $E$. capensis against a drug-sensitive strain of Mycobacterium tuberculosis (H37Rv) using the agar plate method. The activity of the extract was $0.5 \mathrm{mg} / \mathrm{ml}$, and further evaluation was carried out using a rapid radiometric method to confirm the inhibitory activity. The extract exhibited MIC value of $0.1 \mathrm{mg} / \mathrm{ml}$ against the H37Rv strain. These antimycobacterial activities suggest that $E$. capensis extracts deserve further investigation as they may provide secondary metabolites which may lead to tuberculosis drug discovery. 


\section{Antimycoplasmal}

Kama-Kama et al. [47] evaluated antimycoplasmal activities of methanol-dichloromethane (1:1) and methanol stem bark extracts of E. capensis against Mycoplasma mycoides subsp. capri, five strains of M. mycoides subsp. mycoides and one strain of Mycoplasma capricolum subsp. Capricolum using broth microdilution assays. All the extracts showed activities with MIC values ranging from $0.13 \mathrm{mg} / \mathrm{ml}$ to $0.15 \mathrm{mg} / \mathrm{ml}$ [47]. These findings suggest that E. capensis contains phytochemical compounds that might be useful for the treatment and management of respiratory diseases in ruminants.

\section{Antifungal}

Ndukwe et al. [56] evaluated the antifungal activities of methanol leaf, root, and stem bark extracts of E. capensis against Aspergillus niger and Candida albicans using disc diffusion assay. The extracts showed activities with a zone of inhibition ranging from $5 \mathrm{~mm}$ to $20 \mathrm{~mm}$ [56]. Mulaudzi et al. [25] evaluated the antifungal effects of aqueous, acetone, dichloromethane, ethanol, methanol, and petroleum ether bark and leaf extracts of E. capensis against C. albicans using microdilution bioassay with amphotericin as the positive control. The MIC value of the tested fungus ranged from $0.39 \mathrm{mg} / \mathrm{mL}$ to $6.3 \mathrm{mg} / \mathrm{mL}$, while the minimum fungicidal concentration values ranged from $3.13 \mathrm{mg} / \mathrm{mL}$ to $12.5 \mathrm{mg} / \mathrm{mL}$ [25]. Similarly, York etal. [72] assessed antifungal properties of aqueous and dichloromethane-methanol (1:1) leaf extracts of E. capensis against Cryptococcus neoformans using microdilution assay with amphotericin B as the positive control. The dichloromethanemethanol (1:1) extract demonstrated the best activity with MIC value of $0.40 \mathrm{mg} / \mathrm{ml}$, while aqueous extract exhibited activities with MIC value of $16.0 \mathrm{mg} / \mathrm{ml}$ [72]. Mabona et al. [73] evaluated antifungal activities of aqueous and dichlomethane-methanol (1:1) bark and leaf extracts of $E$. capensis using the microtiter plate dilution technique against dermatologically relevant pathogens such as C. albicans, Microsporum canis, and Trichophyton mentagrophytes with amphotericin B as the positive control and acetone and DMSO as negative controls. The extracts showed activities with MIC values ranging from $1.0 \mathrm{mg} / \mathrm{mL}$ to $16.00 \mathrm{mg} / \mathrm{mL}$ and noteworthy antifungal activities were displayed by dichlomethane-methanol bark extracts against $C$. albicans, $M$. canis, and T. mentagrophytes with MIC value of $1.0 \mathrm{mg} / \mathrm{mL}$ [73].

\section{Antihypertensive}

Duncan et al. [19] evaluated antihypertensive properties of ethanol and waterleaf extracts of $E$. capensis using the angiotensin-converting enzyme (ACE) assay. The water and ethanol extracts exhibited ACE inhibition rate of $26 \%$ and $37 \%$, respectively [19]. Kamadyaapa et al. [75] evaluated the in vivo effects of E. capensis leaf ethanolic extracts on the blood pressure of anesthetized normotensive male Wistar rats and conscious weanling Dahl salt-sensitive (DSS) rats, which develop hypertension as they age. The authors assessed contractile or relaxant responses to extracts in the absence or presence of reference drugs in Wistar rat isolated aortic rings precontracted with methoxamine hydrochloride $(10 \mu \mathrm{M})$. The extracts prevented the development of hypertension in weanling genetically hypertensive DSS rats and the in vivo reduction in blood pressure by the extract occurred without significant alterations in the heart rate, suggesting that the in vitro cardiovascular effects of the extract significantly contributed to the hypotensive effects. These findings showed that the hypotensive effect of the extract was in part mediated through modulation of total peripheral resistance of the vascular smooth muscles, as evidenced by the extract's elicited dose-dependent vasorelaxations in endotheliumintact and endothelium-denuded aortic ring preparations [75].

\section{Antioxidant}

Sofidiya et al. [68] evaluated antioxidant activities of leaf extracts of $E$. capensis using the 2,2-diphenyl-1-picrylhydrazyl (DPPH) free radical scavenging and reducing power assays. The extract showed a dosedependent increase in activities ranging from $81.0 \%$ to $96.5 \%$ inhibition on DPPH which was comparable to the activities of the reference $\alpha$-tocopherol which showed $96.9 \%-97.9 \%$ inhibition on DPPH. Reducing power results of the extracts were also dose-dependent and comparable to the activities exhibited by the reference $\alpha$-tocopherol [68] . Aladesanmi et al. [27] evaluated antioxidant activities of methanol leaf extracts of E. capensis using the DPPH free radical scavenging assay. The extract exhibited activities with half maximal effective concentration $\left(\mathrm{EC}_{50}\right)$ value of $13.3 \mu \mathrm{g} / \mathrm{ml}$ which was comparable to $\mathrm{EC}_{50}$ value of $14.2 \mu \mathrm{g} / \mathrm{ml}$ exhibited by rutin, a pure standard antioxidant compound [27]. Amoo et al. [57] evaluated the antioxidant activities of E. capensis using the DPPH free radical scavenging and $\beta$-carotenelinoleic acid model assays after long-term storage in comparison with freshly collected materials. The extracts showed $\mathrm{EC}_{50}$ values of $4.7 \mu \mathrm{g} / \mathrm{ml}-25.5 \mu \mathrm{g} / \mathrm{ml}$ [57]. Tagne et al. [76] evaluated the antioxidant activities of methanol bark extracts of E. capensis using the DPPH and nitric oxide radical scavenging assays. The extract showed activities with DPPH and nitric oxide exhibiting an $\mathrm{IC}_{50}$ value of $15.8 \mu \mathrm{g} / \mathrm{mL}$ and $299 \mu \mathrm{g} / \mathrm{mL}$ which was comparable to $\mathrm{IC}_{50}$ values of $22.7 \mu \mathrm{g} / \mathrm{mL}$ and $108 \mu \mathrm{g} / \mathrm{mL}$ exhibited by the standard gallic acid and ascorbic acid, respectively. Tagne et al. [76] also evaluated the antioxidant activities of hexane, dichloromethane, ethyl acetate, butanol, and methanol bark extracts of E. capensis using DPPH radical scavenging assay. Hexane extracts showed no activity, while dichloromethane showed weak activity with an $\mathrm{IC}_{50}$ value of $366.6 \mu \mathrm{g} / \mathrm{mL}$ and ethyl acetate, butanol and methanol were active with $\mathrm{IC}_{50}$ values ranging from $14.0 \mu \mathrm{g} / \mathrm{mL}$ to $20.2 \mu \mathrm{g} / \mathrm{mL}[76]$.

\section{Antimalarial and antiplasmodial}

Clarkson et al. [77] evaluated antiplasmodial activities of E. capensis aqueous, dichloromethane, dichloromethane-methanol (1:1) fruit and twig extracts against Plasmodium falciparum using the parasite lactate dehydrogenase assay. The dichloromethane-methanol (1:1) fruit extract showed promising activity while dichloromethane-methanol (1:1) twig extract showed weak activity with $\mathrm{IC}_{50}$ values of $10 \mu \mathrm{g} / \mathrm{mL}$ and $18 \mu \mathrm{g} / \mathrm{mL}$, respectively [77]. Muregi et al. [33] evaluated antiplasmodial activities of chloroform, ethyl acetate, and hexane and methanol leaf extracts of E. capensis using the $\left[\mathrm{G}^{-3} \mathrm{H}\right]$ hypoxanthine incorporation assay using chloroquine sensitive and resistant laboratory-adapted strains of $P$. falciparum as the test organism. The hexane extract exhibited no antiplasmodial activity, but chloroform, ethyl acetate, methanol, and water extracts gave good $\mathrm{IC}_{50}$ values $(<5 \mu \mathrm{g} / \mathrm{mL})$ suggesting that E. capensishas a high in vitro antiplasmodial activities. Murata et al. [58] evaluated antiplasmodial activities of compounds $8,22,23,33,34$, 35, 36, and 37 isolated from the stem bark of E. capensis against the chloroquine sensitive strain of P. falciparum. The compounds 8 and 23 showed activities with $\mathrm{IC}_{50}$ values of $6 \mu \mathrm{M}$ and $7 \mu \mathrm{M}$, respectively [58]. Irungu et al. [59] evaluated antiplasmodial activities of leaf and root extracts of E. capensis and compounds isolated from the species against the chloroquine sensitive (D6) and the chloroquine-resistant (W2) strains of P. falciparum. The leaf and root extracts, as well as compounds $22,23,41$, and 42 exhibited moderate activities against the D6 and W2 strains of $P$. falciparum with IC $_{50}$ values ranging from $18.2 \mu \mathrm{M}$ to $82.7 \mu \mathrm{M}[59]$.

Koch et al. [34] evaluated antimalarial activities of bark extracts of E. capensis against a chloroquine-sensitive (D6) strain of $P$. falciparum using a semiautomated microdilution technique. The extract showed activity with an $\mathrm{IC}_{50}$ value of $3.97 \mu \mathrm{g} / \mathrm{ml}$. Muregi et al. [78] evaluated in vivo antimalarial activities of leaf, root, and stem bark extracts of E. capensis in mice against a chloroquine-tolerant Plasmodium berghei NK65, either alone or in combination with chloroquine. The extracts showed activities with parasitemia suppressions ranging from $14.8 \%$ to $33.3 \%$ when extract used alone and $37.9 \%$ to $59.1 \%$ when the extract is used in combination with chloroquine. The extracts gave a $20.0-40.0 \%$ mouse survival when used alone and $20.0-75.0 \%$ when the extract is used in combination with chloroquine. In combination with chloroquine, the extracts showed better chemo-suppression as well as longer mouse survival suggesting synergistic interactions of the extract and chloroquine [78]. Chukwuma [79] evaluated toxicity of hexane and methanol leaf extracts of $E$. capensis by exposing the fourth instar larvae of Anopheles gambiae to different extract concentrations of $62.5 \mu \mathrm{g} / \mathrm{mL}$ to $1000 \mu \mathrm{g} / \mathrm{mL}$ using $\mathrm{N}, \mathrm{N}$-diethyl-3-methylbenzamide as a reference 
insecticide. The hexane fraction displayed mortality at $0.63 \mathrm{mg} / \mathrm{mL}$ with $\mathrm{LC}_{50}$ value of $0.81 \mathrm{mg} / \mathrm{mL}$ which was comparable to the $\mathrm{LC}_{50}$ value of $1.1 \mathrm{mg} / \mathrm{mL}$ exhibited by $\mathrm{N}, \mathrm{N}$-diethyl-3-methylbenzamide, a reference insecticide [79]. Murata et al. [58] evaluated in vivo antimalarial activities of compounds 22 and 23 isolated from the stem bark of E. capensis in mice against artificially induced chloroquine-sensitive $P$. berghei NK 65 using the 4-day suppressive protocol. Each mouse within a group received test compound at a dose of 100,250 , and $500 \mathrm{mg} / \mathrm{kg}$ body weight, once a day for 4 days using a metal catheter. The introduced group received a corresponding volume of distilled water. The compound 23 at a dose of $500 \mathrm{mg} / \mathrm{kg}$ showed moderate parasitemia suppression of 52.9\% against $P$. berghei NK 65 in a mouse model [58]. Therefore, E. capensis extracts showed promising antimalarial and antiplasmodial activities and these findings corroborate the traditional usage of bark, leaves, roots, and stem bark as remedies against malaria in Ethiopia [38], Kenya [33-35], Nigeria [27], and Uganda [37].

\section{Antischistosomal}

Musili et al. [80] evaluated antischistosomal activities of aqueous leaf extracts of $E$. capensis against juvenile, immature adult, and adult worms of Schistosoma mansoni in infected Swiss albino mice. The mice were infected with 90 cercariae each and treated orally with varying doses of aqueous extracts of E. capensis at doses of $25 \mathrm{mg} / \mathrm{kg}$, $50 \mathrm{mg} / \mathrm{kg}, 100 \mathrm{mg} / \mathrm{kg}, 200 \mathrm{mg} / \mathrm{kg}$, and $400 \mathrm{mg} / \mathrm{kg}$ at 2 weeks (juvenile worms), 4 weeks (immature worms), and 7 weeks (adult worms) postinfection with praziquantel (PZQ) and artemether as positive controls while infected untreated group was used as negative controls [80]. The extracts showed significant dose-dependent percentage worm load reduction at different doses ranging from $100 \mathrm{mg} / \mathrm{kg}$ to $400 \mathrm{mg} / \mathrm{kg}$ and the extracts also significantly reduced liver and intestine egg load counts at doses ranging from $50 \mathrm{mg} / \mathrm{kg}$ to $400 \mathrm{mg} / \mathrm{kg}$ which was also dosedependent. These observed activities on both adult and juvenile worms of the parasite were comparable to results obtained using positive control drugs PZQ and artemether [80]. A similar trend was exhibited by PZQ and artemether as positive controls these findings show the potential use of E. capensis in the management of schistosomiasis.

\section{Antitrypanosomal}

Mokoka et al. [81] evaluated antitrypanosomal activities of dichloromethane-methanol root extracts of E. capensis against Trypanosoma brucei rhodesiense using serial dilution. The extract exhibited activity with $\mathrm{IC}_{50}$ value of $1.36 \mu \mathrm{g} / \mathrm{mL}$ with a moderate selectivity index value of 24.3 , indicating its selectivity towards killing the parasites with very little toxicity towards the myoblasts L-6 cells with an $\mathrm{IC}_{50}$ value of $33.0 \mu \mathrm{g} / \mathrm{mL}$ [81]

\section{Antiviral}

Bagla et al. [60] evaluated antiviral activities of hexane, dichloromethane, and methanol root extracts of E. capensis against canine distemper virus, canine parainfluenza virus-2, feline herpesvirus-1, and lumpy skin disease virus using virucidal and attachment assays. Dichloromethane and hexane extracts inhibited all viruses by at least $50 \%$, and the extracts showed weak activities with $\mathrm{EC}_{50}$ values ranging from $30.9 \mu \mathrm{g} / \mathrm{ml}$ to $78.2 \mu \mathrm{g} / \mathrm{ml}$ with selectivity index values of $<1$ [60]. Mulaudzi et al. [25] evaluated anti-HIV activities of aqueous and methanol bark and leaf extracts of E. capensis using a non-radioactive HIV-1 reverse transcriptase (RT) colorimetric ELISA kit. The aqueous bark and leaf extracts as well as methanol leaf extract showed good HIV1 RT inhibition percentage $(70 \%)$ at $1 \mathrm{mg} / \mathrm{mL}$ based on COX-assay, with bark and leaf water extracts exhibiting dose-dependent IC $_{50}$ values of $0.01 \pm 0.00 \mathrm{mg} / \mathrm{mL}$ while leaf methanol extract exhibited $\mathrm{IC}_{50}$ values of $0.39 \pm 0.06 \mathrm{mg} / \mathrm{mL}[25]$.

\section{Cytotoxicity}

Tagne et al. [76] evaluated antiproliferative activities of methanol bark extracts of E. capensis on four cell line panels consisting of NCI-H460 (lung cancer), MCF7 (breast cancer), PC3 (prostate cancer), HeLa (cervix cancer cell), and normal cell 3T3 (mouse cervical cells) using the sulforhodamine-B assay. The extracts showed activity with half-maximal growth inhibition $\left(\mathrm{GI}_{50}\right)$ values ranging from $13.5 \mu \mathrm{g} / \mathrm{mL}$ to $28.8 \mu \mathrm{g} / \mathrm{mL}$ which were comparable to $\mathrm{GI}_{50}$ values of $0.02 \mu \mathrm{g} / \mathrm{mL}-0.70 \mu \mathrm{g} / \mathrm{mL}$ exhibited by the positive control doxorubicin [76]. Tagne et al. [76] evaluated antiproliferative activities of hexane, dichloromethane, ethyl acetate, butanol, and methanol bark extracts of E. capensis against NCI-H460, MCF7, and 3T3 using the sulforhodamine-B assay. The extracts exhibited activities with $\mathrm{GI}_{50}$ values ranging from $10.0 \mu \mathrm{g} / \mathrm{mL}$ to $52.0 \mu \mathrm{g} / \mathrm{mL}$ [76]. Elgorashi et al. [82] evaluated genotoxic activities of dichloromethane bark extract of E. capensis using the Ames assay with $S$. typhimurium strain TA98 and TA100, and VITOTOX ${ }^{\circledR}$ tests with and without metabolic activation. No genotoxic effects were demonstrated by the extracts. Taylor et al. [83] evaluated genotoxic activities of dichloromethane and methanol leaf extract of E. capensis using the cytochalasin B micronucleus test and alkaline comet assay in human white blood cells. The extract showed clastogenic and/or aneuploid activity although micronucleus frequencies were well below that found for the positive control mitomycin at $0.1 \mu \mathrm{g} / \mathrm{mL}$. Reid et al. [84] evaluated mutagenic and antimutagenic activities of dichloromethane and methanol bark extract of E. capensis using the Salmonella or microsome mutagenicity assay (Ames) against S. typhimurium TA98 and TA100 bacterial strains in the presence and absence of metabolic activator S9. No mutagenic and antimutagenic effects were demonstrated by the extracts. Koch et al. [34] evaluated cytotoxicity activities of bark extracts of E. capensis using KB human oral epidermoid cancer cell line with vinblastine (median effective dose $\left[\mathrm{ED}_{50}\right]=0.04 \mu \mathrm{g} / \mathrm{ml}$ ). The extract lacked toxicity to $\mathrm{KB}$ cells with $\mathrm{ED}_{50}$ value $>20.0 \mu \mathrm{g} / \mathrm{ml}$ and selectivity index value $>5.1$. Bagla et al. [60] evaluated the cytotoxicity activities of hexane, dichloromethane, acetone, and methanol root extracts of E. capensis using a colorimetric tetrazolium-based 3-(4,5-dimethylthiazol-2-yl)2,5-diphenyltetrazolium bromide (MTT) assay. Dichloromethane and hexane showed activities with half-maximal cytotoxic concentration $\left(\mathrm{CC}_{50}\right)$ values ranging from $2.5 \mu \mathrm{g} / \mathrm{ml}$ to $43.1 \mu \mathrm{g} / \mathrm{ml}$ with selectivity index values of $<1$. Mulaudzi et al. [26] evaluated genotoxicity activities of dichloromethane, ethanol, petroleum ether, and water bark and leaf extracts of E. capensis using the Ames test, with and without S9 (metabolic activation) against $S$. typhimurium tester strain TA98. The Ames test revealed that all leaf extracts were non-mutagenic toward S. typhimurium strain TA98 but bark extracts induced 50.0 revertant colonies at $500 \mu \mathrm{g} / \mathrm{ml}$ and $50.0 \mu \mathrm{g} / \mathrm{ml}$ and there was no dose-dependent increase and; therefore, the extract could be classified as a weak mutagen [26]. Irungu et al. [59] evaluated the cytotoxicity activities of leaf and root extracts of E. capensis and compounds 6, 7, 16, 22, 23, 25, 28,41 , and 42isolated from the species against the mammalian African monkey kidney (vero), mouse breast cancer (4T1), human larynx carcinoma (HEp2), and human breast cancer (MDA-MB-231) cell lines using MTT assay. The leaf and root extracts exhibited activities against vero, $4 \mathrm{~T} 1$ and $\mathrm{HEp} 2$ with $\mathrm{IC}_{50}$ values ranging from $2.8 \mu \mathrm{M}$ to $97.8 \mu \mathrm{M}$ while compounds $42,25,23$, and 22 showed activities with compound 42 with the highest cytotoxicity with IC ${ }_{50}$ values of $1.4 \mu \mathrm{M}$ and $13.3 \mu \mathrm{M}$ against the HEp2 and 4T1 cells, respectively [59].

\section{Uterotonic}

Sewram et al. [42] evaluated the uterotonic activities of aqueous wood extracts of $E$. capensis using both pregnant and non-pregnant guinea pig uterine smooth muscle in vitro. The extract exhibited positive uterotonic activities. Sewram et al. [42] evaluated the uterotonic activities of compounds 25 and 42 isolated from E. capensis using both pregnant and non-pregnant guinea pig uterine smooth muscle in vitro. The results of this study show that compounds 25 and 42 possess varying degrees of agonist activity on uterine smooth muscle with minor changes in the molecular structure affecting its intrinsic activity on uterine muscle. The compound 25 was observed to mediate its effect through the cholinergic receptor [42].

\section{Toxicity}

Mulholland and Lourine [61] evaluated toxicity activities of hexane seed extract of E. capensis as well as compounds 9, 10, 11, and 13 isolated from the seeds of using the brine shrimps lethality test. The 
extracts at a concentration of $10 \mu \mathrm{g} / \mathrm{ml}, 100 \mu \mathrm{g} / \mathrm{ml}$, and $1000 \mu \mathrm{g} / \mathrm{ml}$, compounds 9 and 10 demonstrated moderate activities of $10 \%$ at the lowest concentration and $61 \%-80 \%$ at the highest concentration [61]. Based on these toxicity evaluations, it can be inferred that E. capensis has some potential toxicity and caution should be exercised when using the species as herbal medicine. These findings corroborate the traditional use of the species as a fish poison in DRC and Nigeria [5].

\section{CONCLUSION}

The present review summarizes the ethnomedicinal uses, phytochemistry, pharmacology, and toxicity of different extracts and compounds of E. capensis, one of several medicinal plants in tropical Africa $[85,86]$. Several phytochemical compounds including alkaloids, anthraquinones, coumarins, flavonoids, glycoflavonoids, glycosides, iridoids, limonoids, polyphenols, phytosteroids, pregnane, saponins, tannins, and withanoides have been identified from different plant parts of the species. In the past 20 years, research on E. capensis focused on evaluating acetylcholinesterase-inhibitory, analgesic and anti-inflammatory, anthelmintic, antibacterial, antifungal, antigonococcal, antimycobacterial, antimalarial and antimycoplasmal, antihypertensive, antioxidant, antiplasmodial, antiproliferative, antischistosomal, antitrypanosomal, antiviral and cytotoxicity activities of the different extracts, and compounds isolated from the species. However, there is not yet enough phytochemical and pharmacological data and clinical research on the majority of ethnomedicinal applications of the species. As revealed by the present review, the vast majority of the documented ethnopharmacological studies reported are in vitro. There is no doubt that these ethnopharmacological studies demonstrated a remarkable potential of E. capensis in the treatment of different human health problems. However, there are limitations associated with the in vitro studies. Therefore, future studies on the species should focus on the mechanism of action of the extracts as well as compounds isolated from the species, in vivo studies and evaluations of target-organ toxicity. Since E. capensis is also used in combination with other plant species in various herbal concoctions, there is a need for extensive research to evaluate synergistic effects of the different extracts or pure isolates to evaluate their ability to enhance the efficiency of the additive mixtures. There is no doubt that E. capensis is a valuable medicinal plant characterized by several phytochemical compounds and pharmacological activities; however, future clinical trials are necessary to clinically support the safety and efficacy of the concoctions prepared from the species.

\section{ACKNOWLEDGMENTS}

The author would like to express his gratitude to the National Research Foundation, South Africa and Govan Mbeki Research and Development Centre, University of Fort Hare for financial support to conduct this study.

\section{AUTHORS' CONTRIBUTIONS}

The authors declare that this work was done by the author named in this article.

\section{CONFLICTS OF INTEREST}

No conflicts of interest are associated with this work.

\section{REFERENCES}

1. Van Wyk BE, Van Oudtshoorn B, Gericke N. Medicinal Plants of South Africa. Pretoria: Briza Publications; 2013.

2. George J, Laing MD, Drewes SE. Phytochemical research in South Africa. S Afr J Sci 2001;97:93-105.

3. Williams VL, Balkwill K, Witkowski ET. A lexicon of plants traded in the Witwatersrand umuthi shops, South Africa. Bothalia 2001:31:71-98.

4. Cunningham AB. African Medicinal Plants: Setting Priorities at the Interface between Conservation and Primary Health Care. Paris: People and Plants Working Paper 1, UNESCO; 1993.

5. Neuwinger HD. Plants used for poison fishing in tropical Africa. Toxicon 2004:44:417-30

6. Pennington TD, Edwards KS. Meliaceae. In: Berry PE, Yatskievych K,
Holst BK, editors. Flora of the Venezuelan Guayana

6. Liliaceae-Myrsinaceae. St. Louis: Missouri Botanical Garden; 2001. p. 528-49.

7. Muellner AN, Samuel R, Chase MW, Coleman A. An evaluation of tribes and generic relationships in Melioideae (Meliaceae) based on nuclear ITS ribosomal DNA. Taxon 2008;57:98-108.

8. International Union for Conservation of Nature (IUCN), Meliaceae: 2018 IUCN Red List of Threatened Species (2018). Available from: http://www.iucnredlist.org/search. [Last accessed on 2018 Jan 12].

9. Louppe D, Oteng-Amoako AA, Brink M. Plant resources of tropical Africa 7: Timbers 1. Leiden: PROTA Foundation, Backhuys Publishers; 2008.

10. Atawodi SE, Atawodi JC. Azadirachta indica (neem): A plant of multiple biological and pharmacological activities. Phytochem Rev 2009;8:601-20.

11. Palmer E, Pitman P. Trees for Southern Africa Covering All Known Indigenous Species in Republic of South Africa, South West Africa, Botswana, Lesotho and Swaziland. Cape Town: A.A. Balkema; 1972.

12. Schmidt E, Lotter M, McCleland W. Trees and shrubs of Mpumalanga and Kruger National Park. Johannesburg: Jacana Media; 2002.

13. Pennington TD, Styles BT. A generic monograph of the Meliaceae. Blumea 1975;22:419-540.

14. Hyde M, Wursten B, Ballings P, Palgrave MC. Flora of Zimbabwe: Species Information: Ekebergia capensis Sparrm. (2018). Available from: https:// www.zimbabweflora.co.zw/speciesdata/species.php?species id $=133540$. [Last accessed on 2018 Apr 15].

15. Palgrave MC. Keith Coates Palgrave Trees of Southern Africa. Cape Town: Struik Publishers; 2002.

16. Mairura FS. Ekebergia capensis Sparrm. In: Louppe D, OtengAmoako AA, Brink M, editors. Plant Resources of Tropical Africa 7: Timbers 1. Leiden: PROTA Foundation, Backhuys Publishers; 2008. p. 227-31.

17. Arnold HJ, Gulumian M. Pharmacopoeia of traditional medicine in Venda. J Ethnopharmacol 1984;12:35-74.

18. Bryant AT. Zulu Medicine and Medicine-Men. Cape Town: C. Struik Publishers; 1966.

19. Duncan AC, Jäger AK, van Staden J. Screening of Zulu medicinal plants for angiotensin converting enzyme (ACE) inhibitors. J Ethnopharmacol 1999;68:63-70.

20. Ochwang'i DO, Kimwele CN, Oduma JA, Gathumbi PK, Mbaria JM, Kiama SG. Medicinal plants used in treatment and management of cancer in Kakamega County, Kenya. J Ethnopharmacol 2014;151:1040-55.

21. Tuasha N, Petros B, Asfaw Z. Medicinal plants used by traditional healers to treat malignancies and other human ailments in Dalle District, Sidama zone, Ethiopia. J Ethnobiol Ethnomed 2018;14:15.

22. Gerstner J. A preliminary checklist of Zulu names of plants with short notes. Bantu Stud 1941;15:277-301.

23. Hutchings A, Scott AH, Lewis G, Cunningham AB. Zulu Medicinal Plants: An Inventory. Pietermaritzburg: University of Natal Press; 1996.

24. Long C. Swaziland's Flora: SiSwati names and uses (2005). Swaziland National Trust Commission, Mbambane. Available from: http://www. sntc.org.sz/index.asp. [Last accessed on 2018 May 7].

25. Mulaudzi RB, Ndhlala AR, Kulkarni MG, Finnie JF, Van Staden J. Antimicrobial properties and phenolic contents of medicinal plants used by the Venda people for conditions related to venereal diseases. J Ethnopharmacol 2011;135:330-7.

26. Mulaudzi RB, Ndhlala AR, Kulkarni MG, Finnie JF, Van Staden J. Antiinflammatory and mutagenic evaluation of medicinal plants used by Venda people against venereal and related diseases. J Ethnopharmacol 2013;146:173-9.

27. Aladesanmi AJ, Iwalewa EO, Adebajo AC, Akinkunmi EO, Taiwo BJ, Olorunmola FO, et al. Antimicrobial and antioxidant activities of some Nigerian medicinal plants. Afr J Tradit Complement Altern Med 2007;4:173-84

28. Njoroge GN, Bussmann RW. Herbal usage and informant consensus in ethno veterinary management of cattle diseases among the Kikuyus (Central Kenya). J Ethnopharmacol 2006;108:332-9.

29. Okello SV, Nyunja RO, Netondo GW, Onyango JC. Ethno botanical study of medicinal plants used by Sabaots of Mt. Elgon, Kenya. Afr J Tradit Complement Altern Med 2010;7:1-10.

30. Wanzala W, Takken W, Mukabana WR, Pala AO, Hassanali A. Ethno knowledge of Bukusu community on livestock tick prevention and control in Bungoma District, Western Kenya. J Ethnopharmacol 2012;140:298-324.

31. Tekle Y. An ethno-veterinary botanical survey of medicinal plants in Kochore District of Gedeo Zone, Southern nations nationalities and peoples regional state (SNNPRs), Ethiopia. J Sci Innovative Res 
2014;3:433-45.

32. Kewessa G, Abebe T, Demessie A. Indigenous knowledge on the use and management of medicinal trees and shrubs in Dale district, Sidama zone, Southern Ethiopia. Ethnobot Res Appl 2015;14:171-82.

33. Muregi FW, Chhabra SC, Njagi EN, Lang'at-Thoruwa CC, Njue WM, Orago AS, et al. Anti-plasmodial activity of some Kenyan medicinal plant extracts singly and in combination with chloroquine. Phytother Res 2004;18:379-84.

34. Koch A, Tamez P, Pezzuto J, Soejarto D. Evaluation of plants used for antimalarial treatment by the maasai of Kenya. J Ethnopharmacol 2005;101:95-9.

35. Njoroge GN, Bussmann RW. Diversity and utilization of antimalarial ethnophytotherapeutic remedies among the Kikuyus (Central Kenya). J Ethnobiol Ethnomed 2006;2:8

36. Gachathi M. Kikuyu Botanical Dictionary: A Guide to Plant Names, Uses and Culture Values. Nairobi: Tropical Botany Press; 2007.

37. Opio DR, Andama E, Kureh GT. Ethnobotanical survey of antimalarial plants in areas of Abukamola, Angeta, Oculokori and Omarari of Alebtong District in Northern Uganda. Eur J Med Plants 2017;21:1-14.

38. Suleman S, Tufa TB, Kebebe D, Belew S, Mekonnen Y, Gashe F, et al. Treatment of malaria and related symptoms using traditional herbal medicine in Ethiopia. J Ethnopharmacol 2018;213:262-79.

39. Regassa R. Assessment of indigenous knowledge of medicinal plant practice and mode of service delivery in Hawassa city, Southern Ethiopia. J Med Plant Res 2013;7:517-35.

40. Meragiaw M, Asfaw Z, Argaw M. The status of ethnobotanical knowledge of medicinal plants and the impacts of resettlement in Delanta, North Western Wello, Northern Ethiopia. Evid Based Complement Alternat Med 2016;2016:24.

41. Pujol J. Natur Africa: The herbalist handbook. Durban: Jean Pujol Natural Healers Foundation; 1990.

42. Sewram V, Raynor MW, Mulholland DA, Raidoo DM. The uterotonic activity of compounds isolated from the supercritical fluid extract of Ekebergia capensis. J Pharm Biomed Anal 2000;24:133-45.

43. Jiofack T, Fokunang C, Guedje N, Kemeuze V, Fongnzossie FE, Nkongmeneck BA, et al. Ethnobotanical uses of medicinal plants of two ethno ecological regions of Cameroon. Int J Med Med Sci 2010;2:60-79.

44. Lulekal E, Asfaw Z, Kelbessa E, Van Damme P. Ethnomedicinal study of plants used for human ailments in Ankober District, North Shewa zone, Amhara Region, Ethiopia. J Ethnobiol Ethnomed 2013;9:63.

45. Mabogo DE. The Ethnobotany of the Vhavenda [M.S. thesis]: Pretoria: University of Pretoria; 1990.

46. Girmay T, Teshome Z. Assessment of traditional medicinal plants used to treat human and livestock ailments and their threatening factors in Gulomekeda District, Northern Ethiopia. Int J Emerg Trends Sci Technol 2017;4:5061-70.

47. Kama-Kama F, Midiwo J, Nganga J, Maina N, Schiek E, Omosa LK, et al. Selected ethno-medicinal plants from Kenya with in vitro activity against major African livestock pathogens belonging to the Mycoplasma mycoides cluster. J Ethnopharmacol 2016;192:524-34

48. Amusan OO, Sukati NA, Dlamini PS, Sibandze FG. Some Swazi phytomedicines and their constituents. Afr J Biotechnol 2007;6:267-72.

49. York T, de Wet H, van Vuuren SF. Plants used for treating respiratory infections in rural Maputaland, KwaZulu-Natal, South Africa. J Ethnopharmacol 2011;135:696-710.

50. Zerabruk S, Yirga G. Traditional knowledge of medicinal plants in Gindeberet District, Western Ethiopia. S Afr J Bot 2012;78:165-9.

51. Rabe T, Van Staden J. Antibacterial activity of South African plants used for medicinal purposes. J Ethnopharmacol 1997;56:81-7.

52. Grierson DS, Afolayan AJ. An ethnobotanical study of plants used for the treatment of wounds in the Eastern Cape, South Africa. J Ethnopharmacol 1999;67:327-32.

53. Getaneh S, Girma Z. An ethnobotanical study of medicinal plants in debre libanos wereda, central Ethiopia. Afr J Plant Sci 2014;8:366-79.

54. Jeruto P, Too E, Mwamburi LA, Amuka O. An inventory of medicinal plants used to treat gynaecological obstetric-urino-genital disorders in South Nandi sub county in Kenya. J Nat Sci Res 2015;5:136-52.

55. Eguale T, Tilahun G, Gidey M, Mekonnen Y. In vitro anthelmintic activities of four Ethiopian medicinal plants against Haemonchus contortus. Pharmacol Online 2006;3:153-65.

56. Ndukwe IG, Habila JD, Bello IA, Adeleye EO. Phytochemical analysis and antimicrobial screening of crude extracts from the leaves, stem bark and root bark of Ekebergia senegalensis A. Juss. Afr J Biotechnol 2006;5:1792-4.

57. Amoo SO, Aremu AO, Moyo M, Van Staden J. Antioxidant and acetyl cholinesterase-inhibitory properties of long-term stored medicinal plants. BMC Complem Altern Med 2012;12:87.

58. Murata T, Miyase T, Muregi FW, Naoshima-Ishibashi Y, Umehara K, Warashina $\mathrm{T}$, et al. Antiplasmodial triterpenoids from Ekebergia capensis. J Nat Prod 2008;71:167-74.

59. Irungu BN, Orwa JA, Gruhnojic A, Fitzpatrick PA, Landberg G, Kimani $\mathrm{F}$, et al. Constituents of the roots and leaves of Ekebergia capensis and their potential antiplasmodial and cytotoxic activities. Molecules 2014;19:14235-46.

60. Bagla VP, McGaw LJ, Eloff JN. The antiviral activity of six South African plants traditionally used against infections in ethno veterinary medicine. Vet Microbiol 2012;155:198-206

61. Mulholland DA, Lourine SE. Limonoids from Ekebergia capensis. Phytochem 1998;47:1357-61.

62. Lontsi D, Ayafor JF, Sondengam BL, Connolly JD, Rycroft DS. The use of two-dimensional long-range $\delta_{C} / \delta_{H}$ correlation in conjunction with the one-dimensional proton-coupled ${ }^{13} \mathrm{C}$ NMR spectrum in the structural elucidation of ekeberginine, a new carbazole alkaloid from Ekebergiasenegalensis (Meliaceae). Tetrahedron Lett 1985;26:4249-52.

63. Okogun JI, Enyenihi VU, Ekong DE. Spectral studies on coumarins and the determination of the constitution of ekersenin by total synthesis. Tetrahedron 1978;34:1221-4.

64. Taylor DA. Ekebergin, a limonoid extractive from Ekebergia capensis. Phytochem 1981;20:2263-5.

65. Mulholland DA, Mahomed HA, Lourine S. A comparison of extractives from the bark of Ekebergia capensis and Ekebergia senegalensis. S Afr J Bot 1997;63:259-60

66. Nishiyama Y, Moriyasu M, Ichimaru M, Tichibana Y, Kato A, Mathenge SG, et al. Acyclic triterpenoids from Ekebergia capensis. Phytochem 1996;42:803-7.

67. Vambe M, Aremu AO, Chukwujekwu JC, Finnie JF, Van Staden J. Antibacterial screening, synergy studies and phenolic content of seven South African medicinal plants against drug-sensitive and-resistant microbial strains. S Afr J Bot 2018;114:250-9.

68. Sofidiya MD, Odukoya OA, Familoni OB, Inya-Agha SI. Free radical scavenging activity of some Nigerian medicinal plant extracts. Pak J Biol Sci 2006;9:1438-41

69. Jäger AK, Hutchings A, Van Staden J. Screening of Zulu medicinal plants for prostaglandin-synthesis inhibitors. J Ethnopharmacol 1996;52:95-100.

70. William A, Ngulde SI, Tijjani MB, Malgwi BU, Sandabe UK. Analgesic activities of the aqueous extract of Ekebergia senegalensis A. Jussstem bark in albino rats. Continental J Pharmacol Toxicol Res 2013;6:17-21.

71. McGaw LJ, Jäger AK, Van Staden J. Antibacterial, anthelmintic and antiamoebic activity in South African medicinal plants. J Ethnopharmacol 2000;72:247-63.

72. York T, Van Vuuren SF, de Wet H. An antimicrobial evaluation of plants used for the treatment of respiratory infections in rural Maputaland, KwaZulu-Natal, South Africa. J Ethnopharmacol 2012;144:118-27.

73. Mabona U, Viljoen A, Shikanga E, Marston A, van Vuuren S. Antimicrobial activity of Southern African medicinal plants with dermatological relevance: From an ethnopharmacological screening approach, to combination studies and the isolation of a bioactive compound. J Ethnopharmacol 2013;148:45-55.

74. Lall N, Meyer JJ. In vitro inhibition of drug-resistant and drug-sensitive strains of Mycobacterium tuberculosis by ethnobotanically selected South African plants. J Ethnopharmacol 1999;66:347-54.

75. Kamadyaapa DR, Gondwe MM, Moodley K, Ojewole JA, Musabayane CT. Cardiovascular effects of Ekebergia capensis Sparrm (Meliaceae) ethanolic leaf extract in experimental animal paradigms. Cardiovase J Afr 2009;20:162-7.

76. Tagne RS, Telefo BP, Nyemb JN, Yemele DM, Njima SN, Goka SM, et al. Anticancer and antioxidant activities of methanol extracts and fractions of some Cameroonian medicinal plants. Asian Pac J Trop Med 2014; 7:s442-7.

77. Clarkson C, Maharaj VJ, Crouch NR, Grace OM, Pillay P, Matsabisa MG, et al. In vitro antiplasmodial activity of medicinal plants native to or naturalised in South Africa. J Ethnopharmacol 2004;92:177-91.

78. Muregi FW, Ishih A, Miyase T, Suzuki T, Kino H, Amano T, et al. Antimalarial activity of methanolic extracts from plants used in Kenyan ethnomedicine and their interactions with chloroquine (CQ) against a CQ-tolerant rodent parasite, in mice. J Ethnopharmacol 2007;111:190-5.

79. Chukwuma OC. Meliaceae plants and vector control of malaria: Larvicidal studies of Ekebergia senegalensis A Juss and Cedrela odorata Linn. Planta Med 2013;79:s145.

80. Musili R, Muregi F, Mwatha J, Muriu D, M'rewa L, Kamau T, et al. Antischistosomal Activity of Azadirachta indica and Ekebergia capensis in Mice Infected with Schistosoma mansoni. Eur J Med Plant 
2015;6:92-102.

81. Mokoka TA, Xolani PK, Zimmermann S, Hata Y, Adams M, Kaiser M, et al. Antiprotozoal screening of 60 South African plants, and the identification of the antitry panosomal germacranolides schkuhrin I and II. Planta Med 2013;79:1380-4.

82. Elgorashi EE, Taylor JL, Maes A, Van Staden J, De Kimpe N, Verschaeve L. Screening of medicinal plants used in South African traditional medicine for genotoxic effects. Toxicol Lett 2003;143:195-207.

83. Taylor JL, Elgorashi EE, Maes A, Gorp UV, De Kimpe N, Van Staden J, et al. Investigating the safety of plants used in South African traditional medicine: Testing for genotoxicity in the micronucleus and alkaline comet assays. Environ Mol Mutagenesis 2003;42:144-54.

84. Reid KA, Maes J, Maes A, Van Staden J, De Kimpe N, Mulholland DA, et al. Evaluation of the mutagenic and antimutagenic effects of South African plants. J Ethnopharmacol 2006;106:44-50.

85. Maroyi A. Dicoma anomala Sond: A review of its botany, ethnomedicine, phytochemistry and pharmacology. Asian J Pharm Clin Res 2018;11:70-7.

86. Ansari I, Patil DT. A brief review on phytochemical and pharmacological profile of Carissa spinarum L. Asian J Pharm Clin Res 2018;11:12-8. 